\title{
COMBINED EFFECT OF ORGANIC AND BIOFERTILIZER ON HERB YIELD AND ESSENTIAL OIL PRODUCTION OF ORIGANUM VULGARE L. PLANTS UNDER SANDY SOIL CONDITIONS
}

\author{
Abd El-Wahab, M.A. ${ }^{(1)}$, Ellabban, Hosny M. ${ }^{(2)}$ and W. M. A. \\ Moghith ${ }^{(1)}$ \\ (1) Medicinal and Aromatic Plants Department, Desert Research \\ Center, Cairo, Egypt, (2) Horticulture Department, Faculty of \\ Agriculture, Tanta University, Tanta, Egypt
}

\begin{abstract}
This study was carried out on Origanum vulgare L. plant during the two successive seasons of 2013 and 2014, at the Experimental Station of Medicinal and Aromatic Plants of Sekem Company, Belbis desert- EL Sharkiya, Egypt. The aim of this research was to study the effect of the combination between compost, biofertilizer and algae extract on the growth, productivity and essential oil production of Origanum vulgare L. plants. The organic fertilization of Sekem compost was added at rates of 5,10 and $15 \mathrm{~m}^{3} /$ fed. A mixture of equal percentages of five strains of bacteria namely, Azotobacter chroococcum, Azospirillum lipoferum (as nitrogen fixing bacteria), Bacillus polymixa, Bacillus megatherium and Pseudomonas fluorescence (as phosphate solubilizing bacteria) was used as a source of biofertlizer. The biofertilizer a mixture at concentration of $1 \times 10^{8} \mathrm{~m}^{\prime}$ was obtained from Sekem Co, Egypt. Algae extract was obtained from Algae Production Unit at the National Research Centre. It was an extract of the algae Spirulina platensis. The results showed that, the highest significant increment for growth and yield characters was resulted from the treatment of algae extract + biofertilizer $+15 \mathrm{~m}^{3}$ compost this combination treatment resulted in the highest mean value of oil yield ( $\mathrm{ml} /$ plant). As general the main chemical constituents of oregano essential oil were carvacrol, p-cymene, ç-terpinene, $\alpha$-thujene, $\alpha$ myrcene, a-terpinene, o-cymene, carvacrol methyl ether and caryophyllene.
\end{abstract}

Keywords: Oregano, Origanum vulgare, algae extract, compost, yield, biofertilization, volatile oil.

\section{INTRODUCTION}

It is of interest to increase the production of medicinal and aromatic plants to avoid chemical therapy side effects on human health, as it has a major role in the treatment of human and animal diseases. Chemical fertilizers and pesticides used in agriculture for increasing yield and controlling pests can contaminate the water, air, food, lowed soil fertility as well as have bad influence on growth of soil microorganisms and human health (Abdel-Ghany, 2007 and Hamed, 2011). 
Most widely used is the genus Origanum (family Lamiaceae) (from the Greek words oros- mountain and hill and ganos- ornament). Oregano is the most valued spice and the common name for a general aroma and flavor primarily derived from more than 60 plant species used worldwide as a seasoning. Origanum spp. (Lamiaceae) includes more than 70 species, subspecies, varieties, and hybrids, and most of the species are shrubs (Kintzios, 2002). One of the most important commercially grown species is Origanum vulgare subsp. hirtum, which is endemic to the Mediterranean area (Skoula and Harborne, 2002).

Oregano is found in many areas and is a perennial shrub native to the dry, rocky limestone soils in the mountainous area of southern Europe and southwest Asia. It is also cultivated because of its uses as a herb and its healing properties,, which have been known since Antiquity (Bariceric and Bartal, 2002).In addition, the significance of herbs such as oregano has increased in recent years, especially with the interest in growing alternative crops and in nutraceutical and functional foods. Sixty percent of all are recorded to grow in Turkey, indicating this country as the gene center of Origanum (Kintzios, 2002). Origanum is known widely in the world of herbs and spices for its volatile oils. Oregano is the commercial name of those species that are rich in the phenolic monoterpenoids, mainly carvacrol, occasionally thymol, while marjoram is the commercial name of those that are rich in bicyclic monoterpenoids cis- and trans-sabinene hydrate (Kintzios, 2002).

The essential oil of Origanum vulgare subsp. vulgare has a great potential of antimicrobial activity against all 10 bacteria, and 15 fungi and yeast species tested. The result may suggest that the essential oil $O$. vulgare subsp. vulgare possesses compounds with antimicrobial properties as well as antioxidant activity, and therefore can be used as a natural preservative ingredient in food and/or pharmaceutical industry (Sahin et al., 2004). Origanum vulgare subsp. hirtum showed antioxidant activity (Milos et al., 2000). Origanum vulgare ethanolic extract and essential oil revealed antibacterial properties and antioxidant activity (Bárbara et al., 2013).

As a valuable medicinal plant, chemical free production and food safety is one of the major issues related to fresh products (Antunes and Cavaco, 2010). Recently, the production of chemical-free medicinal and aromatic plants has been the main goal of many researchers and producers in order to ensure the high quality and safety of the product. Therefore, it would be beneficial to use alternatives to chemical fertilizers or at least to minimize the levels of these chemical fertilizers (Hellal et al., 2011). 
Bio-fertilizers are microbial preparations containing living cells of different organisms (bacteria, fungi, cyanobacteria, etc.), which have the ability to mobilize plant nutrients in soil from unusable to usable form through biological processes. These fertilizers are not harmful to crops or other plants like the chemical fertilizers. They let the plants grow in a healthy environment. Use of bio fertilizers in the soil, makes the plants healthy as well as protect them from getting many diseases. They are also environment friendly and do not cause the pollution of any sort (Sadhana, 2014).

In the last two decades, bio fertilizers have been increasingly used in modern agriculture due to the extensive knowledge in rhizospheric biology and the discovery of the promotive microorganisms. Azospirillum, Azotobacter chroococcum and Azospirillum lipoferum (confirmed as nitrogen fixing bacteria), Bacillus polymixa, Bacillus megatherium var phosphaticum and Pseudomonas fluorescence (confirmed as phosphate solubilizing bacteria) are known as plant growth promoting rhizobacteria (Abdel Wahab and Hassan, 2013).

Moreover, it is known that compost is required to improve the quality of soil organic matter (Rivero et al, 2004) by various ways. When composts are applied to soil, not only degradable substrates and nutrients are supplied, but also a wide range of microorganisms (Ryckeboer et al, 2003), including harmless heterotrophy but potentially also plant and human pathogens. Compost as an organic material influences agricultural sustainability by improving chemical, physical, biological properties of soils, the fertility and structure of the soil and the moisture holding capacity (Saha et al, 2008).

Considering the importance of organic and biofertilizers for sustainable agriculture and the necessity to reduce chemical fertilizers application in agricultural, this study was conducted to evaluate the effect of organic and biofertilization on growth, production and chemical constituents of Origanum vulgare L. subsp hirtum plants.

\section{MATERIALS AND METHODS}

The present study was carried out during the two successive seasons of 2013 \& 2014 at the Experimental Station of Medicinal and Aromatic Plants of Sekem Company, Belbis , EL-Sharkiya

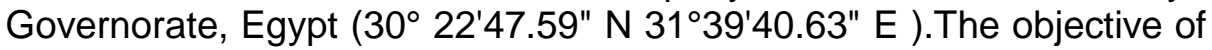
this work was to study the effect of organic and biofertilization on growth, productivity and chemical constituents of Origanum vulgare subsp. hirtum L. plants.

Oregano seeds were imported from Germany by Pharmasaat Co, (straße am west bahnh of D-06556 Artem), Tel/Fax: $++49(0) 3466 / 324599$, by Sekem Co. Seeds were sown in the nursery 
on the first week of November in both seasons. The Seedlings were transplanted from nursery to the experimental site on $18{ }^{\text {th }}$ March for the first season and on $20^{\text {th }}$ March for the second one .

All soil and water samples were analyzed in the Desert Research Center laboratories according to Rainwater and Thatcher (1960) are presented in Tables (A\&B)

Table (A): The physical and chemical properties of the experimental soil

\begin{tabular}{|c|c|c|c|c|c|c|c|c|c|c|c|c|c|c|}
\hline \multirow{2}{*}{$\begin{array}{l}\text { Soil } \\
\text { type }\end{array}$} & \multirow{2}{*}{$\begin{array}{l}p \\
H\end{array}$} & \multirow{2}{*}{$\begin{array}{l}\text { E.C. } \\
\text { (dS } \\
\left.m^{-1}\right)\end{array}$} & \multirow{2}{*}{$\begin{array}{l}\text { O. } \\
\text { M. } \\
(\%)\end{array}$} & \multicolumn{4}{|c|}{ Cations (meq/l) } & \multicolumn{3}{|c|}{$\begin{array}{l}\text { Anions } \\
\text { (meq/l) }\end{array}$} & \multirow{2}{*}{$\begin{array}{l}\text { TDS } \\
\text { (mg/ } \\
\text { I) }\end{array}$} & \multirow{2}{*}{\begin{tabular}{|c}
$\mathrm{N}$ \\
$(\mathbf{m g}$ \\
/I)
\end{tabular}} & \multirow{2}{*}{$\begin{array}{c}\mathbf{P} \\
(\mathrm{mg} \\
/ \mathrm{I})\end{array}$} & \multirow{2}{*}{$\begin{array}{c}\mathrm{K} \\
(\mathrm{mg} \\
\mathrm{I})\end{array}$} \\
\hline & & & & $\mathrm{Ca}_{+}^{+}$ & $\mathrm{Mg}_{+}^{+}$ & $\underset{+}{\mathrm{Na}}$ & $\mathrm{K}^{+}$ & $\mathrm{HCO}_{3}{ }^{-}$ & $\begin{array}{l}\text { So } \\
4^{--}\end{array}$ & $\mathrm{Cl}^{-}$ & & & & \\
\hline $\begin{array}{l}\text { Fine } \\
\text { San } \\
\text { dy }\end{array}$ & 5 & 0.93 & 1.9 & $\begin{array}{c}2.9 \\
8\end{array}$ & $\begin{array}{c}1.0 \\
5\end{array}$ & $\begin{array}{c}4.7 \\
0\end{array}$ & $\begin{array}{l}0 . \\
59\end{array}$ & 2.45 & $\begin{array}{c}3.3 \\
6\end{array}$ & $\begin{array}{l}3 . \\
55\end{array}$ & $\begin{array}{c}584 . \\
9\end{array}$ & 71.2 & 5.12 & 65.4 \\
\hline
\end{tabular}

Table (B): Water analysis of the irrigation water

\begin{tabular}{|c|c|c|c|c|c|c|c|c|c|c|}
\hline \multirow{2}{*}{$\begin{array}{l}\text { TDS } \\
\mathrm{mg} / \mathrm{l}\end{array}$} & \multirow{2}{*}{$\begin{array}{l}p \\
\mathrm{H}\end{array}$} & \multirow{2}{*}{$\begin{array}{c}\mathrm{EC} \\
\left(\begin{array}{c}\mathrm{ESm} \\
1\end{array}\right)\end{array}$} & \multicolumn{4}{|c|}{ Soluble cations (mg/l.) } & \multicolumn{4}{|c|}{ Soluble anions (mg/l.) } \\
\hline & & & $\mathrm{Ca}^{++}$ & $\mathrm{Mg}^{+}$ & $\mathrm{Na}^{+}$ & $\overline{\mathrm{K}^{+}}$ & $\mathrm{CO}_{3}^{-}$ & $\mathrm{HCO}$ & $\mathrm{SO}_{4}{ }^{-}$ & $\mathrm{CL}^{-}$ \\
\hline 233.6 & $\begin{array}{c}7 . \\
2\end{array}$ & 397 & 33.2 & 11.0 & 33.0 & 5.0 & 21.0 & 112.9 & 44.5 & 29 \\
\hline
\end{tabular}

Before planting, rock phosphate was added at $100 \mathrm{~kg} / \mathrm{fed}$ for all experimental plots. The soil was divided into four plots each plot was provided with compost at three levels. After soil preparation, drip irrigation system was installed at $60 \mathrm{~cm}$ between rows and $30 \mathrm{~cm}$ between plants within the row. Drippers were set up at 2.0 liter/hour/plant every day.

Compost fertilizer was supplied by Sekem Co., Egypt from the company own compost production facility. Plants were treated with compost fertilization at 5,10 and $15 \mathrm{~m}^{3} / \mathrm{fed}$. Compost was added during soil preparation one day before seedling transplanting. After adding compost, soil was irrigated until saturation. Analysis of the added compost is presented in Table (C).

Table (C): Chemical analysis of the used compost

\begin{tabular}{|c|c|c|c|c|c|c|c|c|c|c|c|c|c|}
\hline \multirow[b]{2}{*}{ pH } & \multirow{2}{*}{ 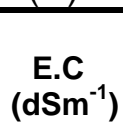 } & \multicolumn{4}{|c|}{$\begin{array}{c}\text { Soluble cations } \\
\text { (meq//). }\end{array}$} & \multicolumn{3}{|c|}{ Soluble anions } & \multirow{2}{*}{ Ash } & \multirow[b]{2}{*}{ O.M\% } & \multirow[b]{2}{*}{$\mathrm{N} \%$} & \multirow[b]{2}{*}{ P\% } & \multirow[b]{2}{*}{ K\% } \\
\hline & & $\mathrm{Ca}^{++}$ & $\mathrm{Mg}^{+}$ & $\mathrm{Na}^{+}$ & $\mathrm{K}^{+}$ & $\mathrm{HCO}_{3}{ }^{3}$ & $\mathrm{Cl}^{-}$ & $\mathrm{SO}_{4}=$ & & & & & \\
\hline 10 & 3.10 & 15.00 & 45.0 & 90.0 & 30.0 & 45.00 & 10.0 & 140.5 & 9.00 & 65.00 & 2.0 & 1.5 & 1.00 \\
\hline
\end{tabular}


Biofertilizer was added as a mixture of equal percentages of five strains of bacteria namely: Azotobacter chroococcum, Azospirillum lipoferum, Bacillus polymixa, B.megatherium and Pseudomonas fluorescence $\left(1 \times 10^{8} / \mathrm{ml}\right)$ which were obtained from Sekem Co, Egypt. The biofertilizer treatment was prepared by dilution of $1 \mathrm{~L}$ mixture with 20 I of tap water and added as a soil drench at $50 \mathrm{ml}$ per plant four times per season. Application of biofertilizer was after transplanting at 30 and 45 days, and after the first cut at 15 and 30 days, immediately after biofertilizer application, irrigation was done.

Algae extract $1 \%$ was obtained from Algae Production Unit at the National Research Center. It was an extract of the algae Spirulina platensis. The Algae extract treatment was prepared by dilution of $1 \mathrm{~L}$ mixture with 50 I of tap water and added as a spray on plant every 30 days per season. Application was after transplanting with 30 days.

The treatments were conducted as follows:

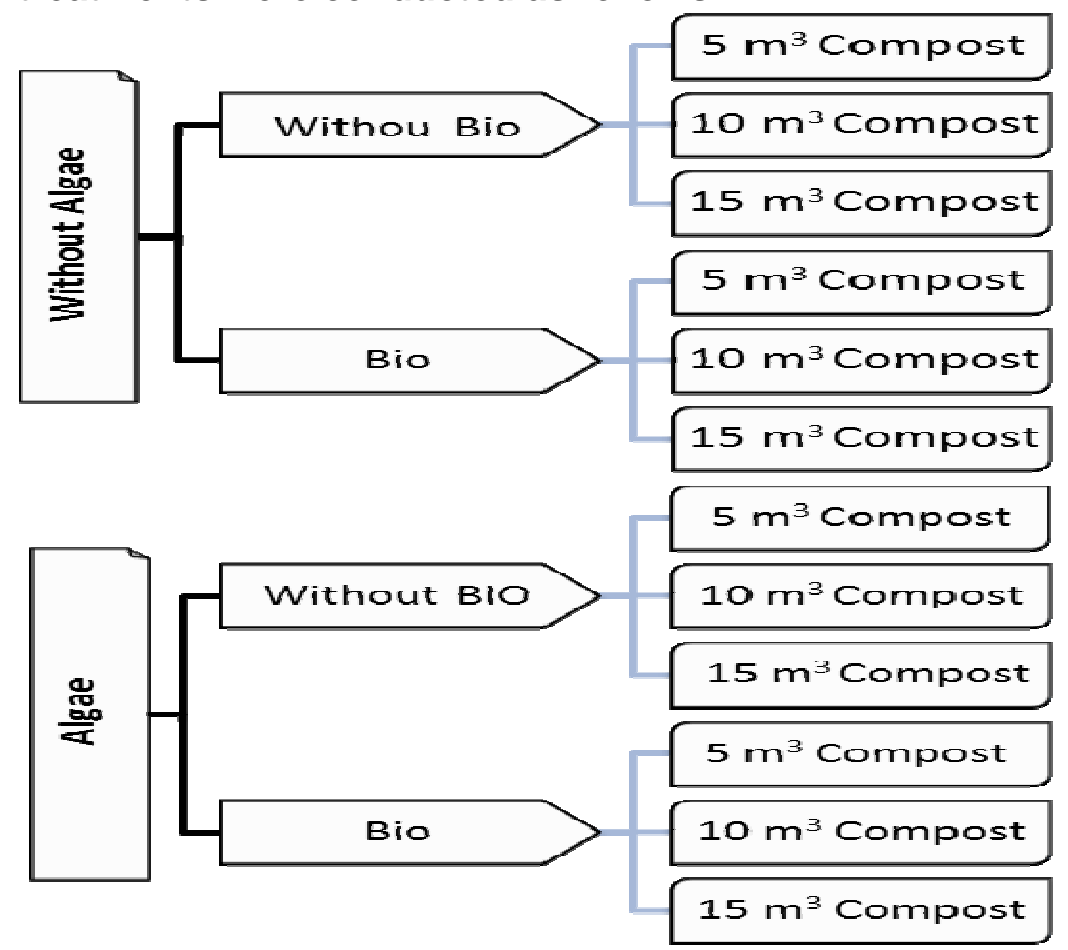

Harvesting of oregano fresh herb was done twice per season on July $1^{\text {st }}$ and November $1^{\text {st }}$ and data were the mean of the two cuts.

The following parameters were recorded at harvesting time: 


\section{1- Plant vegetative growth}

- Herb fresh weight ( $\mathrm{g} / \mathrm{plant}$ and $\mathrm{kg} / \mathrm{fed})$.

- Herb dry weight (g/plant and $\mathrm{kg} / \mathrm{fed})$.

- Yield of dry leaves ( $\mathrm{g} / \mathrm{plant}$ and $\mathrm{kg} / \mathrm{fed})$.

\section{2- Determination of essential oil:}

-Essential oil percentage (\%).

-Essential oil yield per plant (ml).

-Essential oil constituents by GC-MS analysis.

Oregano volatile oil \% was determined by hydro distillation according to the method described in British Pharmacopoeia (1963).

The GC-MS analysis for oil samples from the second season was carried out at the Central Laboratory of National Research Center, Giza. Essential oil GC/ Mass analysis was performed using a HewlettPackard 5890 A series 11 instrument equipped with flame ionization detector (FID) and a carbon wax fused silica column $(50 \mathrm{~m} \times 0.25 \mathrm{~mm}$. i. d., film thickness $0.32 \mu \mathrm{m}$ ). Initial column temperature was $50 \mathrm{Co}$ and held for 3 minutes, then raised to $60 c^{\circ}$ by rate $3.0 C^{\circ}$ per minute and raised to $260 \mathrm{C}^{\circ}$ by rate $3.0 \mathrm{C}^{\circ}$ per minute and hold at $260 \mathrm{C}^{\circ}$ for 5 minutes. The volatile oil components were identified by comparing their retention times and mass spectrum with those of standards, NIST library of the GC-MS system and literature data.

Identifications were made by library searches (Adams, 2007) combining MS and retention data of authentic compounds by comparison of their $\mathrm{GC}$ retention indices (RI) with those of the literature or with those of standards available in our laboratories (Adams, 2007).

The layout of the experiment was a split-split plot design with three replicates using algae extract as the main plot, biofertilizer as sub plot and compost in the sub sub plot. The results were statistically analyzed using MSTAT program, USA. Means were compared using LSD test at 0.05 level according to Sendecor and Cochran, (1982).

\section{A- Vegetative growth:}

\section{RESULTS AND DISCUSSION}

\section{A-1-Fresh weight ( $\mathrm{g} / \mathrm{plant}$ and $\mathrm{kg} / \mathrm{fed})$ :}

As presented in table (1) for the effect of the interaction between algae, biofertilization and compost on fresh weight/plant and yield fresh weight per fed, in both seasons, the significantly heaviest plants resulted from the treatment of algae + biofertilization $+15 \mathrm{~m}^{3}$ compost/fed. However the lightest plants, in both seasons, resulted from the treatment of without (algae and biofertilization) $+5 \mathrm{~m}^{3}$ compost/fed. Also the highest yield fresh weight per fed. was resulted from the treatment of algae + biofertilization $+15 \mathrm{~m}^{3}$ compost/fed. 
These results were in parallel line with those achieved by Kandeel and Sharaf (2003) who indicated that, Azotobacter chroococcum showed an increment in fresh weight of Marjorana hortensis L. plants. On mint plants (Mentha arvensis L.), Rajamanickam et al. (2011) revealed that, application of $100 \%$ NPK + vermicompost at $5 \mathrm{t} \mathrm{ha}^{-1}+$ consortium of biofertilizers significantly increased the fresh herbage yield. Edris et al. (2003) on Origanum majorana and El-Sherbeny et al. (2007) on Ruta graveolens L. reported that compost significantly improved most vegetative growth characters as fresh weight of leaves and stems. Shariatmadari et al. (2011) on tomato, cucumber and squash showed that addition of all algae extract can enhance fresh weight of leaf and stem and Bindhu (2013) on Pisum sativum, found that $20 \%$ concentration of aqueous extract of Azolla promoted the fresh weight of plant.

Table (1): Effect of interaction between algae extract, biofertilizer and compost on herb fresh weight (g/plant) and yield fresh weight $(\mathrm{kg} / \mathrm{fed})$ of oregano plant during 2013 and 2014 seasons

\begin{tabular}{|c|c|c|c|c|c|c|c|c|c|c|c|c|c|c|}
\hline \multirow{2}{*}{\multicolumn{3}{|c|}{ Algae x Bio x Compost }} & \multicolumn{6}{|c|}{ Fresh weight (g/plant) } & \multicolumn{6}{|c|}{ Yield fresh weight (kg/fed) } \\
\hline & & & \multicolumn{3}{|c|}{2013} & \multicolumn{3}{|c|}{2014} & \multicolumn{3}{|c|}{2013} & \multicolumn{3}{|c|}{2014} \\
\hline Algae & Bio & Comp & $\begin{array}{l}1^{\text {st }} \\
\text { cut }\end{array}$ & $\begin{array}{l}2^{\text {nd }} \\
\text { cut }\end{array}$ & $\begin{array}{l}\text { Total } \\
\text { yield }\end{array}$ & $\begin{array}{l}1^{\text {st }} \\
\text { cut }\end{array}$ & $\begin{array}{l}2^{\text {nd }} \\
\text { cut }\end{array}$ & $\begin{array}{l}\text { Total } \\
\text { yield }\end{array}$ & $\begin{array}{l}1^{\text {st }} \\
\text { cut }\end{array}$ & $\begin{array}{l}2^{\text {nd }} \\
\text { cut }\end{array}$ & $\begin{array}{l}\text { Total } \\
\text { yield }\end{array}$ & $\begin{array}{l}1^{\text {st }} \\
\text { cut }\end{array}$ & $\begin{array}{l}2^{\text {nd }} \\
\text { cut }\end{array}$ & $\begin{array}{l}\text { Total } \\
\text { yield }\end{array}$ \\
\hline \multirow{6}{*}{ Without } & \multirow{3}{*}{ Without } & $5 \mathrm{~m}^{3}$ & 59.78 & 60.44 & 120.22 & 60.11 & 58.33 & 118.44 & 1395 & 1410 & 2805 & 1403 & 1361 & 2764 \\
\hline & & $10 \mathrm{~m}^{3}$ & 59.89 & 68.89 & 128.78 & 56.44 & 64.78 & 121.22 & 1397 & 1607 & 3004 & 1317 & 1512 & 2829 \\
\hline & & $15 \mathrm{~m}^{3}$ & 70.56 & 75.67 & 146.23 & 66.45 & 70.44 & 136.89 & 1646 & 1766 & 3412 & 1551 & 1644 & 3195 \\
\hline & \multirow{3}{*}{ With } & $5 \mathrm{~m}^{3}$ & 58.11 & 78.56 & 136.67 & 69.56 & 72.11 & 141.67 & 1356 & 1833 & 3189 & 1623 & 1683 & 3306 \\
\hline & & $10 \mathrm{~m}^{3}$ & 74.63 & 85.89 & 160.52 & 77.67 & 90.78 & 168.45 & 1741 & 2004 & 3745 & 1812 & 2118 & 3930 \\
\hline & & $15 \mathrm{~m}^{3}$ & 84.43 & 98.67 & 183.10 & 80.78 & 94.56 & 175.34 & 1970 & 2302 & 4272 & 1885 & 2206 & 4091 \\
\hline \multirow{6}{*}{ With } & \multirow{3}{*}{ Without } & $5 \mathrm{~m}^{3}$ & 80.22 & 87.78 & 168.00 & 83.11 & 89.89 & 173.00 & 1872 & 2048 & 3920 & 1939 & 2097 & 4036 \\
\hline & & $10 \mathrm{~m}^{3}$ & 95.97 & 95.00 & 190.97 & 97.00 & 100.00 & 197.00 & 2239 & 2217 & 4456 & 2263 & 2333 & 4596 \\
\hline & & $15 \mathrm{~m}^{3}$ & 99.78 & 113.80 & 213.58 & 102.90 & 108.60 & 211.50 & 2328 & 2655 & 4983 & 2401 & 2534 & 4935 \\
\hline & \multirow{3}{*}{ With } & $5 \mathrm{~m}^{3}$ & 134.60 & 146.50 & 281.10 & 129.20 & 143.40 & 272.60 & 3141 & 3418 & 6559 & 3015 & 3346 & 6361 \\
\hline & & $10 \mathrm{~m}^{3}$ & 137.00 & 149.30 & 286.30 & 131.2 & 143.40 & 274.60 & 3197 & 3484 & 6681 & 3061 & 3346 & 6407 \\
\hline & & $15 \mathrm{~m}^{3}$ & 150.30 & 157.4 & 307.70 & 149.10 & 153.30 & 302.40 & 3507 & 3673 & 7180 & 3479 & 3577 & 7056 \\
\hline \multicolumn{3}{|l|}{$\operatorname{LSD}_{0.05}$} & 21.93 & 26.93 & & 18.62 & 14.15 & & 482.5 & 592.4 & & 409.7 & 311.3 & \\
\hline
\end{tabular}

\section{A-2-Dry weight (g/plant and $\mathrm{kg} / \mathrm{fed})$ :}

The effect of interactions between algae, biofertilizer and compost treatments on plant dry weight and dry yield /fed. are shown in Table (2).

The results indicated that, the maximum plant dry weight as well as dry yield /fed. were obtained when oregano plants were treated with algae, biofertilizer and compost at $15 \mathrm{~m}^{3}$, these results were 
observed in all cuts in both seasons. With note that the three levels of compost in the first cut of the first season, compost at 10 and $15 \mathrm{~m}^{3}$ in the second cut in the same season and the first cut in the second season there were non significant differences among them. These results were coincided with those obtained by Al-Fraihat et al. (2011) showed that, marjoram treated with halex-2 biofertilizers gave the highest values of herb dry yield.

The stimulatory effect of the treatment of algae + biofertilization $+\quad 15 \mathrm{~m}^{3}$ compost/fed. on both fresh and dry weight/plant may be due to the stimulatory role of algae, bio and organic fertilization on the plant physiological processes (Toaima, 2005; Abdel-Moneim and Abd-Allah, 2008 and Saha et al, 2008;).

Table (2): Effect of the interaction between algae extract, biofertilizer and compost on herb dry weight ( $\mathrm{g} / \mathrm{plant})$ and $(\mathrm{kg} / \mathrm{fed})$ of oregano during 2013 and 2014 seasons

\begin{tabular}{|c|c|c|c|c|c|c|c|c|c|c|c|c|c|c|}
\hline \multirow{2}{*}{\multicolumn{3}{|c|}{ Algae $x$ Bio $x$ Compost }} & \multicolumn{6}{|c|}{ Dry weight (g/plant) } & \multicolumn{6}{|c|}{ Dry weight (kg/fed) } \\
\hline & & & \multicolumn{3}{|c|}{2013} & \multicolumn{3}{|c|}{2014} & \multicolumn{3}{|c|}{2013} & \multicolumn{3}{|c|}{2014} \\
\hline Algae & Bio & Comp & $\begin{array}{l}1^{\mathrm{st}} \\
\text { cut }\end{array}$ & $\begin{array}{l}2^{\text {nd }} \\
\text { cut }\end{array}$ & $\begin{array}{l}\begin{array}{l}\text { Total } \\
\text { yield }\end{array} \\
\end{array}$ & $\begin{array}{l}1^{\mathrm{st}} \\
\text { cut }\end{array}$ & $\begin{array}{l}2^{\text {nd }} \\
\text { cut }\end{array}$ & $\begin{array}{l}\text { Total } \\
\text { yield }\end{array}$ & $\begin{array}{l}1^{\mathrm{st}} \\
\text { cut }\end{array}$ & $\begin{array}{l}2^{\text {nd }} \\
\text { cut }\end{array}$ & $\begin{array}{l}\text { Total } \\
\text { yield }\end{array}$ & $\begin{array}{l}1^{\mathrm{st}} \\
\text { cut }\end{array}$ & $\begin{array}{l}2^{\text {nd }} \\
\text { cut }\end{array}$ & $\begin{array}{l}\text { Total } \\
\text { yield }\end{array}$ \\
\hline \multirow{6}{*}{ Without } & \multirow{3}{*}{ Without } & $5 \mathrm{~m}^{3}$ & 19.07 & 20.67 & 39.74 & 19.59 & 18.67 & 38.26 & 444.9 & 482.3 & 927.2 & 457.1 & 435.6 & 892.7 \\
\hline & & $10 \mathrm{~m}^{3}$ & 21.08 & 22.53 & 43.61 & 20.00 & 21.97 & 41.97 & 491.9 & 525.7 & 1017.6 & 466.7 & 512.6 & 979.3 \\
\hline & & $15 \mathrm{~m}^{3}$ & 24.92 & 23.89 & 48.81 & 22.56 & 24.10 & 46.66 & 581.5 & 557.4 & 1138.9 & 526.4 & 562.3 & 1088.7 \\
\hline & \multirow{3}{*}{ With } & $5 \mathrm{~m}^{3}$ & 23.93 & 23.51 & 47.44 & 23.00 & 22.67 & 45.67 & 558.4 & 548.6 & 1107.0 & 536.7 & 529.0 & 1065.7 \\
\hline & & $10 \mathrm{~m}^{3}$ & 28.40 & 28.97 & 57.37 & 25.47 & 30.53 & 56.00 & 662.7 & 676.0 & 1338.7 & 594.3 & 712.4 & 1306.7 \\
\hline & & $15 \mathrm{~m}^{3}$ & 30.09 & 34.22 & 64.31 & 29.33 & 32.09 & 61.42 & 702.1 & 798.5 & 1500.6 & 684.4 & 748.8 & 1433.2 \\
\hline \multirow{6}{*}{ With } & \multirow{3}{*}{ Without } & $5 \mathrm{~m}^{3}$ & 25.84 & 31.21 & 57.05 & 27.57 & 31.85 & 59.42 & 602.9 & 728.2 & 1331.1 & 643.3 & 743.2 & 1386.5 \\
\hline & & $10 \mathrm{~m}^{3}$ & 30.15 & 31.67 & 61.82 & 33.00 & 33.33 & 66.33 & 703.5 & 739.0 & 1442.5 & 770.0 & 777.7 & 1547.7 \\
\hline & & $15 \mathrm{~m}^{3}$ & 36.62 & 36.78 & 73.40 & 34.11 & 35.22 & 69.33 & 854.5 & 858.2 & 1712.7 & 795.9 & 821.8 & 1617.7 \\
\hline & \multirow{3}{*}{ With } & $5 \mathrm{~m}^{3}$ & 43.67 & 42.87 & 86.54 & 40.43 & 39.54 & 79.97 & 1019.0 & 1000.3 & 2019.3 & 943.4 & 922.6 & 1866.0 \\
\hline & & $10 \mathrm{~m}^{3}$ & 43.74 & 49.00 & 92.74 & 42.33 & 43.87 & 86.20 & 1019.0 & 1143.3 & 2162.3 & 987.7 & 1023.6 & 2011.3 \\
\hline & & $15 \mathrm{~m}^{3}$ & 50.56 & 52.22 & 102.78 & 46.56 & 50.50 & 97.06 & 1179.7 & 1218.4 & 2397.8 & 1086.4 & 1178.3 & 2264.7 \\
\hline \multicolumn{3}{|l|}{ LSD $_{0.05}$} & 10.57 & 8.03 & & 5.71 & 5.91 & & 232.6 & 176.6 & & 125.6 & 130.0 & \\
\hline
\end{tabular}

\section{A-3-Leaves dry weight (g/plant) and ( $\mathrm{kg} / \mathrm{fed}$.$) :$}

The effects of interactions between algae, biofertilizer and compost treatments on leaves dry weight ( $\mathrm{g} / \mathrm{plant})$ and yield of leaves dry weight (kg/fed.) are shown in Table (3). The results indicated that, the maximum values of leaves dry weight/plant as well as yield of leaves dry weight/fed. were obtained from treating oregano plants with algae, biofertilizer and compost at $15 \mathrm{~m}^{3}$, these results were observed in all cuts in both seasons although there were non-significant 
differences among compost at $5,10,15 \mathrm{~m}^{3}$ in the first cut of the first season and compost at 10 and $15 \mathrm{~m}^{3}$ in second cut of the first season and both cuts in the second season.

Table (3): Effect of the interaction between algae extract, biofertilizer and compost on leaves dry weight $(\mathrm{g})$ / plant and $(\mathrm{kg}) / \mathrm{fed}$ of oregano during 2013 and 2014 seasons

\begin{tabular}{|c|c|c|c|c|c|c|c|c|c|c|c|c|c|c|}
\hline \multirow{2}{*}{\multicolumn{3}{|c|}{ Algae $\mathrm{x}$ Bio $\mathrm{x}$ Compost }} & \multicolumn{6}{|c|}{ Leaves d.w./plant } & \multicolumn{6}{|c|}{ Leaves d.w./fed } \\
\hline & & & \multicolumn{3}{|c|}{2013} & \multicolumn{3}{|c|}{2014} & \multicolumn{3}{|c|}{2013} & \multicolumn{3}{|c|}{2014} \\
\hline Algae & Bio & Comp & $\begin{array}{l}1^{\text {st }} \\
\text { cut }\end{array}$ & $\begin{array}{l}2^{\text {nd }} \\
\text { cut }\end{array}$ & $\begin{array}{l}\begin{array}{l}\text { Total } \\
\text { yield }\end{array} \\
\end{array}$ & $\begin{array}{l}1^{\text {st }} \\
\text { cut }\end{array}$ & $\begin{array}{l}2^{\text {nd }} \\
\text { cut }\end{array}$ & $\begin{array}{l}\text { Total } \\
\text { yield }\end{array}$ & $\begin{array}{l}1^{\text {st }} \\
\text { cut }\end{array}$ & $\begin{array}{l}2^{\text {nd }} \\
\text { cut }\end{array}$ & $\begin{array}{l}\begin{array}{l}\text { Total } \\
\text { yield }\end{array} \\
\end{array}$ & $\begin{array}{l}1^{\text {st }} \\
\text { cut }\end{array}$ & $\begin{array}{l}2^{\text {nd }} \\
\text { cut }\end{array}$ & $\begin{array}{l}\text { Total } \\
\text { yield }\end{array}$ \\
\hline \multirow{6}{*}{ Without } & \multirow{3}{*}{ Without } & $5 \mathrm{~m}^{3}$ & 9.22 & 10.27 & 19.49 & 9.39 & 9.28 & 18.67 & 215.1 & 239.6 & 454.7 & 220.0 & 216.5 & 436.5 \\
\hline & & $10 \mathrm{~m}^{3}$ & 10.62 & 11.11 & 21.73 & 9.31 & 11.63 & 20.94 & 247.8 & 259.2 & 507.0 & 217.2 & 271.4 & 488.6 \\
\hline & & $15 \mathrm{~m}^{3}$ & 13.26 & 13.12 & 26.38 & 12.38 & 12.44 & 24.82 & 309.4 & 306.1 & 615.5 & 288.9 & 290.3 & 579.2 \\
\hline & \multirow{3}{*}{ With } & $5 \mathrm{~m}^{3}$ & 12.43 & 12.91 & 25.34 & 12.62 & 12.40 & 25.02 & 290.0 & 301.2 & 591.2 & 294.5 & 289.3 & 583.8 \\
\hline & & $10 \mathrm{~m}^{3}$ & 17.21 & 17.73 & 34.94 & 15.43 & 18.60 & 34.03 & 401.6 & 413.7 & \begin{tabular}{|l|l|}
815.3 \\
\end{tabular} & 360.0 & 434.0 & 794.0 \\
\hline & & $15 \mathrm{~m}^{3}$ & 19.05 & 21.27 & 40.32 & 17.91 & 20.93 & 38.84 & 444.5 & 496.3 & 940.8 & 417.9 & 488.4 & 906.3 \\
\hline \multirow{6}{*}{ With } & \multirow{3}{*}{ Without } & $5 \mathrm{~m}^{3}$ & 12.77 & 15.75 & 28.52 & 13.11 & 15.80 & 28.91 & 298.0 & 367.5 & 665.5 & 305.9 & 368.7 & 674.6 \\
\hline & & $10 \mathrm{~m}^{3}$ & 15.04 & 17.24 & 32.28 & 17.00 & 18.84 & 35.84 & 350.9 & 402.3 & 753.2 & 396.7 & 439.6 & 836.3 \\
\hline & & $15 \mathrm{~m}^{3}$ & 19.48 & 19.69 & 39.17 & 20.03 & 21.01 & 41.04 & 454.5 & 459.4 & 913.9 & 467.4 & 490.2 & 957.6 \\
\hline & \multirow{3}{*}{ With } & $5 \mathrm{~m}^{3}$ & 26.49 & 26.33 & 52.82 & 25.67 & 26.84 & 52.51 & 618.1 & 614.4 & 1232.5 & 599.0 & 626.3 & 1225.3 \\
\hline & & $10 \mathrm{~m}^{3}$ & 27.48 & 31.33 & 58.81 & 28.07 & 30.07 & 58.14 & 641.2 & 731.0 & 1372.2 & 655.0 & 701.6 & 1356.6 \\
\hline & & $15 \mathrm{~m}^{3}$ & 32.39 & 33.62 & 66.01 & 31.69 & 32.74 & 64.43 & 755.8 & 784.5 & 1540.3 & 739.4 & 763.9 & 1503.3 \\
\hline \multicolumn{3}{|l|}{ LSD $_{0.05}$} & 5.98 & 5.09 & & 4.55 & 2.79 & & 131.5 & 111.9 & & 100.2 & 61.35 & \\
\hline
\end{tabular}

These results were in line with the results of herb dry weight/plant and herb dry yield /fed. and were in agreement with those obtained by

El-Sherbeny et al. (2007) on Ruta graveolens $\mathrm{L}$. who recorded that compost significantly improved dry weight of leaves and Shariatmadari et al. (2011) on tomato, cucucmber and squash who showed that addition of all algal extract can enhance dry weight of leaf.

\section{B- Oil percentage and oil yield per plant:}

The effect of interactions of algae, biofertilizer and compost treatments are shown in Table (4). The results showed significant differences between most treatments. The highest values of oil percentage resulted from treated plants without algae, without biofertilizer and $5 \mathrm{~m}^{3}$ compost. While in the first cut in first season the highest values resulted from treatment of algae, with biofertilizer and compost at $15 \mathrm{~m}^{3}$ with non significant differences between compost levels. In the first cut of the second season the highest values resulted from treatment algae, with biofertilizer and compost at any levels. 
Table (4): Effect of the interaction between algae extract, biofertilizer and compost on volatile oil percentage and oil yield (ml/plant) of oregano plant during 2013 and 2014 seasons

\begin{tabular}{|c|c|c|c|c|c|c|c|c|c|c|}
\hline \multirow{2}{*}{\multicolumn{3}{|c|}{ Algae $\mathrm{x}$ bio $\mathrm{x}$ compost }} & \multicolumn{4}{|c|}{ Oil (\%) } & \multicolumn{4}{|c|}{ Oil per plant (ml) } \\
\hline & & & \multicolumn{2}{|c|}{2013} & \multicolumn{2}{|c|}{2014} & \multicolumn{2}{|c|}{2013} & \multicolumn{2}{|c|}{2014} \\
\hline Alge & Bio & Comp & $1^{\text {st }}$ cut & $2^{\text {nd }}$ cut & $1^{\text {st }}$ cut & $2^{\text {nd }}$ cut & $1^{\text {st }}$ cut & $2^{\text {nd }}$ cut & $1^{\text {st }}$ cut & $2^{\text {nd }}$ cut \\
\hline \multirow{6}{*}{ Without } & \multirow{3}{*}{ Without } & $5 \mathrm{~m}^{3}$ & 1.52 & 0.89 & 1.53 & 0.92 & 0.25 & 0.18 & 0.30 & 0.17 \\
\hline & & $10 \mathrm{~m}^{3}$ & 1.36 & 0.79 & 1.38 & 0.80 & 0.29 & 0.18 & 0.28 & 0.18 \\
\hline & & $15 \mathrm{~m}^{3}$ & 1.23 & 0.76 & 1.25 & 0.77 & 0.31 & 0.19 & 0.28 & 0.18 \\
\hline & \multirow{3}{*}{ With } & $5 \mathrm{~m}^{3}$ & 1.17 & 0.65 & 1.17 & 0.66 & 0.28 & 0.16 & 0.27 & 0.15 \\
\hline & & $10 \mathrm{~m}^{3}$ & 1.19 & 0.63 & 1.73 & 0.63 & 0.34 & 0.18 & 0.30 & 0.19 \\
\hline & & $15 \mathrm{~m}^{3}$ & 1.04 & 0.63 & 1.05 & 0.62 & 0.31 & 0.21 & 0.31 & 0.20 \\
\hline \multirow{6}{*}{ With } & \multirow{3}{*}{ Without } & $5 \mathrm{~m}^{3}$ & 1.16 & 0.50 & 1.12 & 0.51 & 0.30 & 0.16 & 0.31 & 0.16 \\
\hline & & $10 \mathrm{~m}^{3}$ & 0.94 & 0.40 & 0.98 & 0.39 & 0.28 & 0.13 & 0.33 & 0.13 \\
\hline & & $15 \mathrm{~m}^{3}$ & 0.73 & 0.37 & 0.72 & 0.38 & 0.27 & 0.14 & 0.24 & 0.13 \\
\hline & \multirow{3}{*}{ With } & $5 \mathrm{~m}^{3}$ & 1.16 & 0.35 & 1.15 & 0.36 & 0.51 & 0.15 & 0.47 & 0.14 \\
\hline & & $10 \mathrm{~m}^{3}$ & 1.04 & 0.33 & 1.10 & 0.34 & 0.45 & 0.16 & 0.47 & 0.15 \\
\hline & & $15 \mathrm{~m}^{3}$ & 1.07 & 0.33 & 1.00 & 0.34 & $0.54 \mathrm{~A}$ & 0.17 & 0.47 & 0.17 \\
\hline \multicolumn{3}{|l|}{ LSD $_{0.05}$} & 0.19 & 0.08 & 0.11 & 0.08 & 0.09 & 0.054 & 0.077 & 0.002 \\
\hline
\end{tabular}

Similar results were obtained by Mahfouz (2003) who showed that biofertilization of Majorana hortensis increased essential oil percentage and oil yield per plant. Toaima (2005) on Achillea millefolium L. recorded that, in the presence of second chemical fertilizers level of NPK (300 kg ammonium sulfate $+200 \mathrm{~kg}$ calcium super phosphate + $50 \mathrm{~kg}$ potassium sulfate/fed.) plus organic manure $\left(15 \mathrm{~m}^{3} / \mathrm{fed}\right.$ sheep manure) + biofetilizer (a mixture of Azotobacter chroococcum, Azospirillum lipoferum and Bacillus megatherium) one addition per month enhanced essential oil percentage and oil yield per plant. AlFraihat et al. (2011) showed that treating marjoram plants with halex-2 biofertilizers gave the highest significant values of volatile oil percentage and oil yield/plant and Khalil et al. (2008) and EL-Leithy et al. (2013) found that all levels of compost significantly increased oil (\%) and oil yield (ml/plant) of sage.

\section{3- Oil yield (I/ fed.):}

The effect of interactions of algae, biofertilizer and compost treatments on oil yield per feddan are shown in Table (5). The highest oil yield per feddan was obtained from the treatment of algae, with bio fertilizer and compost at $15 \mathrm{~m}^{3}$ while in the second season resulted 
from treatment of algae, with bio fertilizer and compost at $10 \mathrm{~m}^{3}$ as these results were obtained from treatment of algae, with bio fertilizer and compost at $15 \mathrm{~m}^{3}$.

Table (5): Effect of the interaction between algae extract, biofertilizer and compost on oil yield (l/fed) of oregano during 2013 and 2014 seasons

\begin{tabular}{|c|c|c|c|c|c|c|c|c|}
\hline \multirow{2}{*}{\multicolumn{3}{|c|}{ Algae $\mathrm{x}$ bio $\mathrm{x}$ compost }} & \multicolumn{6}{|c|}{ Oil yield ( I/fed.) } \\
\hline & & & \multicolumn{3}{|c|}{2013} & \multicolumn{3}{|c|}{2014} \\
\hline Algae & Bio & Comp & $1^{\text {st }}$ cut & $2^{\text {nd }}$ cut & $\begin{array}{l}\text { Total } \\
\text { yield }\end{array}$ & $1^{\text {st }}$ cut & $2^{\text {nd }}$ cut & $\begin{array}{l}\text { Total } \\
\text { yield }\end{array}$ \\
\hline \multirow{6}{*}{$\begin{array}{l}\text { With } \\
\text { out }\end{array}$} & \multirow{3}{*}{ Without } & $5 \mathrm{~m}^{3}$ & 5.83 & 4.20 & 10.03 & 7.00 & 3.97 & 10.97 \\
\hline & & $10 \mathrm{~m}^{3}$ & 6.77 & 4.20 & 10.97 & 6.53 & 4.20 & 10.73 \\
\hline & & $15 \mathrm{~m}^{3}$ & 7.23 & 4.43 & 11.66 & 6.53 & 4.20 & 10.73 \\
\hline & \multirow{3}{*}{ With } & $5 \mathrm{~m}^{3}$ & 6.53 & 3.73 & 10.26 & 6.30 & 3.50 & 9.80 \\
\hline & & $10 \mathrm{~m}^{3}$ & 7.93 & 4.20 & 12.13 & 7.00 & 4.43 & 11.43 \\
\hline & & $15 \mathrm{~m}^{3}$ & 7.23 & 4.90 & 12.13 & 7.23 & 4.67 & 11.90 \\
\hline \multirow{6}{*}{ With } & \multirow{3}{*}{ Without } & $5 \mathrm{~m}^{3}$ & 7.00 & 3.73 & 10.73 & 7.23 & 3.73 & 10.96 \\
\hline & & $10 \mathrm{~m}^{3}$ & 6.53 & 3.03 & 9.56 & 7.70 & 3.03 & 10.73 \\
\hline & & $15 \mathrm{~m}^{3}$ & 6.30 & 3.27 & 9.57 & 5.60 & 3.03 & 8.63 \\
\hline & \multirow{3}{*}{ With } & $5 \mathrm{~m}^{3}$ & 11.90 & 3.50 & 15.40 & 10.97 & 3.27 & 14.24 \\
\hline & & $10 \mathrm{~m}^{3}$ & 10.50 & 3.73 & 14.23 & 10.97 & 3.50 & 14.47 \\
\hline & & $15 \mathrm{~m}^{3}$ & 12.60 & 3.97 & 16.57 & 10.97 & 3.97 & 14.94 \\
\hline \multicolumn{3}{|l|}{$\operatorname{LSD}_{0.05}$} & 2.16 & 0.97 & & 1.60 & 0.73 & \\
\hline
\end{tabular}

These findings were in agreement with these reported by Mahfouz (2003) who showed that biofertilization on Majorana hortensis increased oil yield per feddan, Abdelaziz et al. (2007) on Rosmarinus officinalis $\mathrm{L}$. found that the treated plants by a mixture of compost and microorganisms showed essential oil production.

\section{4- Essential oil constituents:}

Data of the effect of organic and biofertilization tretments on oil constituents of Origanum vulgare L. subsp hirtum in two cuts during the two seaseons are presented in Table (6).

As general the main chemical constituents of oregano essential oil were carvacrol, p-cymene, ç-terpinene, a-thujene, a-myrcene, $\alpha$ terpinene, o-cymene, carvacrol methyl ether and caryophyllene).

Carvacrol was the most dominant component in oregano essential oil composition for the different treatments. Carvacrol is a monoterpenoid phenol, it has a characteristic pungent, warm odor. The 
quality of oregano oil is determined by the carvacrol percentage in the oil. Skoula and Harborne (2002) reported that carvacrol is the dominant component of its essential oil. Andreas and Dimitra (2013) found that carvacrol is the dominant component in the essential oil of O.vulgare subsp. hirtum. Lagouri et al. (1993), Aeschbach et al. (1994) and Yanishlieva et al. (1999) revealed that antioxidant effect of this plant is as a result of carvacrol. Mastelic et al. (2008) reported its antimicrobial and antioxidant properties and in addition, revealed carvacrol's antiproliferative activity on tumor cells of Hela.

Table (6): The main components (\%) of oregano volatile oil treated by compost and their combination with biofertilizers treatments of the second season

\begin{tabular}{|c|c|c|c|c|c|c|c|c|c|c|c|}
\hline Components & RT & $\mathrm{C} 1$ & $\mathrm{~B}+\mathrm{C} 1$ & $\mathrm{~B}+\mathrm{C} 2$ & $\mathrm{~B}+\mathrm{C} 3$ & $A+C 1$ & $\mathrm{~A}+\mathrm{C} 2$ & $A+C 3$ & $\begin{array}{c}\mathrm{A}+\mathrm{B}+ \\
\mathrm{C} 1\end{array}$ & $\begin{array}{c}\mathrm{A}+\mathrm{B}+ \\
\mathrm{C} 2\end{array}$ & $\begin{array}{c}\mathrm{A}+\mathrm{B}+ \\
\mathrm{C} 3\end{array}$ \\
\hline$\alpha$-Thujene & 8.82 & 8.08 & 6.03 & 4.9 & 5.31 & 9.83 & 8.04 & 6.52 & 4.44 & 11.01 & 6.81 \\
\hline a-Pinene & 10.39 & 0.38 & & & & & & & & & \\
\hline Sabinene & 10.45 & 0.5 & & & & & & & 1.73 & & \\
\hline 1-Octen-3-Ol & 10.94 & & & 0.94 & & & & & & & \\
\hline a-Myrcene & 11.15 & 3.85 & 2.01 & & 1.95 & 3.97 & 3.18 & 0.59 & 1.92 & & 3.13 \\
\hline$\alpha$-Terpinene & 11.9 & 0.66 & & & 0.74 & & & & 1.00 & & \\
\hline o-Cymene & 12.4 & 5.2 & 19.52 & & & 15.49 & 16.94 & 19.38 & 34.61 & & 15.73 \\
\hline p-Cymene & 12.7 & 27.9 & 35.12 & 56.3 & 42.9 & 12.7 & 25.55 & 28.52 & 10.58 & 27.15 & 21.92 \\
\hline cis-Ocimene & 12.97 & & & & 1.95 & & 1.66 & & & & 1.06 \\
\hline ç-Terpinene & 14.08 & 28.2 & 11.36 & 8.27 & 10.6 & 20.72 & 19.79 & 15.96 & 10.17 & 22.25 & 21.43 \\
\hline Borneol & 17.45 & 0.43 & & 1.28 & 0.56 & 0.78 & & 0.46 & 0.62 & 1.62 & 0.46 \\
\hline $\begin{array}{l}\text { Carvacrol methyl } \\
\text { ether }\end{array}$ & 20.21 & 0.63 & 1.48 & 1.49 & 2.09 & 0.79 & 2.68 & 1.49 & 1.47 & 4.26 & 1.00 \\
\hline Carvacrol & 23.67 & 23 & 23.8 & 25.7 & 33.3 & 34.34 & 22.16 & 26.55 & 32.45 & 33.72 & 27.67 \\
\hline Caryophyllene & 26.03 & 0.42 & 0.67 & 0.66 & 0.61 & 1.02 & & 0.53 & 0.51 & & 0.53 \\
\hline à-Humulene & 27.04 & & & & & 0.35 & & & & & \\
\hline Germacrene-D & 27.86 & 0.38 & & & & & & & 0.27 & & 0.27 \\
\hline$\alpha$-Bisabolene & 28.73 & 0.31 & & & & & & & & & \\
\hline $\begin{array}{l}\text { Caryophyllene } \\
\text { oxide }\end{array}$ & 30.87 & & & 0.42 & & & & & 0.23 & & \\
\hline Total & & 99.94 & 99.99 & 99.96 & 99.99 & 99.99 & 100 & 100 & 100 & 100 & 100 \\
\hline
\end{tabular}

$A^{*}$ means algae extract. $B^{*}$ means biofertilizers mixture. $C 1^{*}$ means compost at $5 \mathrm{~m}^{3}$.

$\mathrm{C} 2^{\star}$ means compost at $10 \mathrm{~m}^{3}$. $\mathrm{C} 3^{*}$ means compost at $15 \mathrm{~m}^{3}$.

It was obvious from previous data that the different fertilization treatments have a remarkable influence on carvacrol percentage in the oil. The highest carvacrol percentage was obtained from the 
treatments:- algae $+5 \mathrm{~m}^{3}$ compost/fed, algae +biofertilization $+10 \mathrm{~m}^{3}$ compost and biofertilization $+15 \mathrm{~m}^{3}$ compost while the lowest carvacrol percentage in the oil was obtained from the control treatment:- algae $+10 \mathrm{~m}^{3}$ compost.

These results were in agreement with those obtained by EI Leithy et al. (2006) on rosemary who found that the highest oil content and essential oil constituents (alpha-pinene, $\beta$-pinene, limonene, 1-8cineole, linalool, camphor, $\beta$-terpineol, borneol, terpinen 4- ol, carvone, thymol, carvacrol, linalylacetate, geranylacetate, $\beta$-caryophyllene, caryophyllene oxide) were highly significant increased under biofertilizer (Azotobacter vinelandii) treatments. Hendawy et al. (2010) on Thymus vulgaris $\mathrm{L}$. reported that $20 \mathrm{~m}^{3}$ compost fed ${ }^{-1}$ combined with $10 \mathrm{I} \mathrm{fed}^{-1}$ of tea compost and /or feldspar, rock phosphate at the level of $150 \mathrm{~kg} \mathrm{fed}^{-1}$ were superior in most cases of growth characters, yield and oil percentage of Thymus vulgaris.

\section{REFERENCES}

Abd EI Moniem, Eman A. and Abd-Allah A.S.E. (2008). Effect of green alga cells extract as foliar spray on vegetative growth, yield and berries quality of superior grapevines. American-Eurasian $\mathrm{J}$. Agric. \& Environ. Sci., 4 (4): 427-433.

Abdel Wahab, M. M. and A. Z. A. Hassan. (2013). Response of fennel plants to organic biofertilizer in replacement of chemical fertilization. Top Class Journal of Agric. Res. 1(3):29-35.

Abd El-Ghany, A. M. E (2007). Agrochemical studies on some oregano species. M.Sc. Thesis, Fac. Agric. Al-Azhar Univ., Egypt.

Abdelaziz, M.; Pokluda, R. and Abdelwahab, M. (2007). Influence of compost, microorganisms and NPK fertilizer upon growth, chemical composition and essential oil production of Rosmarinus Officinalis L. Not. Bot. Hort. Agrobot. Cluj, Vol 35 (1): 86-90.

Adams, R.P. (2007). Identification of essential oil components by gas chromatography/mass spectroscopy. Allured, Carol Stream, Illinois, and USA.

Aeschbach, R.; Loliger, J.; Scott, C.; Murcia, A.; Butler, J.; Halliwell, B. and Aruoma, O. I. (1994). Antitoxidant actions of thymol, carvacrol, 6- gingerol, zingerone and hydroxytyrosol. Food Chem. Toxicol., 32: 31-36.

Al-Fraihat, A. H.; Al-dalain, S. Y. A.; Al-Rawashdeh, Z. B.; Abu-Darwish, M. S. and Al-Tabbal, J. A. (2011). Effect of organic and biofertilizers on growth, herb yield and volatile oil of marjoram plant grown in Ajloun region, Jordan. J. Med. Plants Res., 5 (13): 2822-2833.

Andreas, J. K. and Dimitra, E. K. S. (2013). Field studies of nitrogen application on Greek Oregano (Origanum vulgare ssp. Hirtum 
(link) letswaart) essential oil during two cultivation seasons. Ind. Crops Prod., 46:246 -252.

Antunes, M.D.C and Cavaco A.M. (2010). The use of essential oils for postharvest decay control. A review. Flavour Fragr J., 25:351366.

B arbara Teixeira; Ant onio Marques; Cristina Ramos; Carmo Serrano; Ol'ivia Matos; Nuno R Neng; Jos'e M F Nogueira; Jorge Alexandre Saraiva and Maria Leonor Nunes (2013). Chemical composition and bioactivity ofdifferent oregano (Origanum vulgare) extractsand essential oil. J Sci Food Agric., 93(11): 2707-2714.

Bariceric, D. and Bartal, T. (2002). The biological/pharmacological activity of the Origanum genus. In: Kintzios, S.E. (Ed.), Oregano: The genera Origanum and Lippia. Taylor and Francis, London, p: 177-214.

Bindhu, K. B. (2013). Effect of Azolla extract on growth performance of Pisum sativum. Int. Res. J. Biological Sci., 2(10):88-90.

British Pharmacopoeia (1963). Determination of Volatile Oil in Drugs. Pharmaceutical Press, London.W.C.I.

Edris, A. E.; Shalaby, A. and Fadel, H. M. (2003). Effect of organic, agriculture practices on the volatile aroma components of some essential oil plants growing in Egypt. II: Sweet marjoram (Origanum majorana L.) essential oil. Flavour Fragr J, 18(4): 345-351.

El- Leithy, S.; El-Meseiry, T. A. and Abdallah, E. F. (2006). Effect of biofertilizer, cell stabilizer and irrigation regime on rosemary herbage oil yield and quality. J. Appl. Sci. Res, 2(10): 773-779.

El-Leithy A.S, El-Hanafy S.H, Omer E.A and El-Sayed A.A.A.(2013) Effect of nitrogen and potassium biofertilization on growth yield and essential oil production of white horehound Marrubium vulgare L. J Hort Sci Ornamen Plants, 5(1):46-59.

El-Sherbeny, S. E.; Hussein, M. S. and Khalil, M. Y. (2007). Improving the Production of Ruta graveolens L. Plants Cultivated under different compost levels and various sowing distance. American-Eurasian J. Agric. \& Environ. Sci., 2(3):271-281.

Hamed, E. S. (2011). Studies of effect of fertilization and irrigation levels on growth, production and chemical contents of Brassica alba L. under Sinai condition. Ph.D. Thesis, Fac. Agric., Kafr ElSheikh Univ., Egypt.

Hellal, S.; Mahfouz, A. and Hassan, F. A. S. (2011). Partial substitution of mineral nitrogen fertilizer by bio-fertilizer on Anethum graveolens L. plant Agric. Biol. J. N. Am., 2(4):652-660.

Hendawy, S. F.; Ezz El-Din, A. A.; Aziz, E. E. and Omer, E. A. (2010). Productivity and oil quality of Thymus vulgaris $\mathrm{L}$. under organic fertilization conditions. Ozean Journal of Applied Sciences, 3(2): 203-216.

Kandeel, A. M. and Sharaf, M. S. (2003). Productivity of Majorana hortensis, L. plants as influenced by the interaction between 
mineral and biological fertilization. J. Agric. Sci. Mansoura Univ., 28: 1373-1389.

Khalil, M. Y.; Kandil, M. A. M. and Swaefy Hend, M. F. (2008). Effect of three different compost levels on fennel and salvia growth character and their essential oils. Res. J. Agric. \& Biol. Sci, 4(1): 34-39.

Kintzios, S. E. (2002). Profile of the multifaceted prince of the herbs. In: Kintzios S.E. (Ed.) Oregano: The genera Origanum and Lippia. Medicinal and Aromatic plants Industrial Profiles 25. Taylor and Francis/ CRC Press USA, p: 3-8, 236-242.

Lagouri, V.; Blekas, G.; Tsimidou, M.; Kokkini, S. and Boskou, D. (1993). Composition and antioxidant activity of essential oils from Oregano plants grown wild in Greece. Z. Lenbenson. Unters. Forsch. 197:20-23.

Mahfouz, S. A. S. (2003). Effect of biofertilization on growth and oil production of marjoram (Majorana hortensis Moench.) plant. Ph.D. Thesis, Fac. Agric., Cairo Univ., Egypt.

Mastelic, J.; Jerkovic, I.; Blazevic, I.; Poljak-Blazi, M.; Borovic, S.; IvancicBace, I.; Smrecki, V.; Zarkovic, N.; Brcic-Kostic, K.; Vikic-Topic, D. and Muller, N. (2008). Comparative study on the antioxidant and biological activities of carvacrol, thymol and eugenol derivatives. J. Agric. Food Chem., 56:3989-3996.

Milos, M.; Mastelic, J. and Jerkovic, I. (2000). Chemical composition and antioxidant of glycosidically bound volatile compounds from oregano (Origanum vulgare L. ssp. hirtum). Food Chem., 71: 7983.

Rainwater, F. H. and Thatcher, L. L. (1960). Methods for Collection and Analysis of Water Samples, USGS Water Supply Paper 1454, Washington, D.C.

Rajamanickam, V.; Venkatesan, S. and Shakila, A. (2011). Effect of organic manures, consortium of biofertilizers and inorganic fertilizers on yield, nutrient uptake and profitability of mint (Mentha Arvensis L.). Asian J Hort., 6 (1) :191-194.

Rivero, C.; Chirenje, T.; Ma, L.Q. and Martinez, G. (2004). Influence of compost on soil organic matter quality under tropical conditions. Geoderma., 123: 355-361.

Ryckeboer, J.; Mergaert, J.; Vaes, K.; Klammer, S.; De Clercq, D.; Coosemans, J.; Insam, H. and Swings, J. (2003). A survey of bacteria and fungi occurring during composting and selfheating processes. Ann Microbiol, 53: 349-410.

Sadhana, B. (2014). "Arbuscular mycorrhizal fungi (AMF) as a biofertilizer”. Int. J. Curr. Microbiol. App. Sci., 3(4):384-400.

Saha, S.; B. L. Mina; K. L. Gopinath; S. Kundu and H. S. Gupta. (2008). Relative changes in phosphatase activities as influenced by source and application rate of organic composts in field crops. Biores Technol., 99:1750-1757.

Sahin, F.; Güllüce, M.; Daferera, D.; Sökmen, A.; Sökmen, M.; Polissiou, M.; Agar, G. and özer, H. (2004). Biological activities of the 
essential oils and methanol extract of Origanum vulgare ssp.vulgare in the Eastern Anatolia region of Turkey. Food Control, 15: 549-557.

Shariatmadari, Z.; Riahi, H. and Shokravi, S. (2011). Study of soil bluegreen algae and their effect on seed germination and plant growth of vegetable crops. Rosta niha., 12(2): 101-110.

Skoula, M. and Harborne, J. B. (2002). The taxonomy and chemistry of Origanum. In: Kintzios, S.E. (Ed.), Oregano: The Genera Origanum and Lippia. Taylor and Francis, London, p:67-108.

Snedecor, G. W. and W. G. Cochran. (1982). Statistical Methods. The lowa State Univ., Press., Ames., lowa, U.S.A., 507 pp.

Toaima, I. M. W. (2005). Production of yarrow (Achillea millefolium L.) under Sinai conditions. M. Sc. Thesis, Fac. Agric., AL-Azhar Univ.

Yanishlieva, N.V.; Marinova, E. M. and Gordon, M. H. (1999). Antioxidant activity and mechanism of action of thymol and carvacrol in two lipid systems. Food Chem., 64: 59-66.

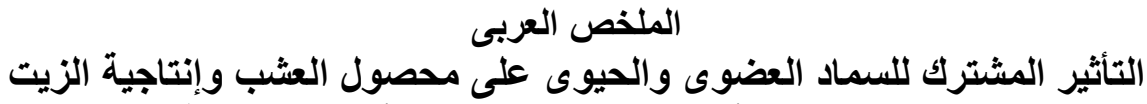

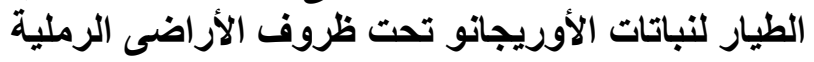

(1)

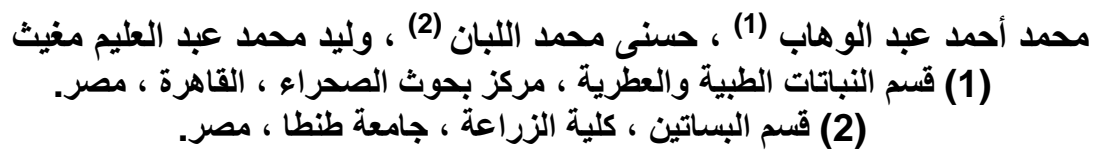

و الإنتاجية و إنتاج الزيت الطيار لنباتات الأوريجانو. تم إضافة التسميد العضوى بكمبوست سيكم بمعدل 5 ، 10 بـ

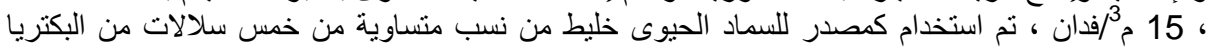
(بكتريا مثبتة وهى Azotobacter chroococcum, Azospirillum lipoferum Pseudomonas Bacillus polymixa, Bacillus megatherium و للنيتروجين)

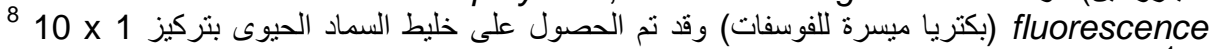

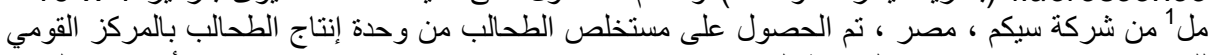

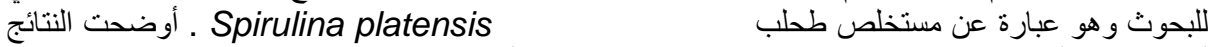

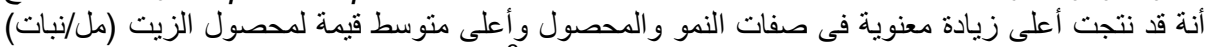

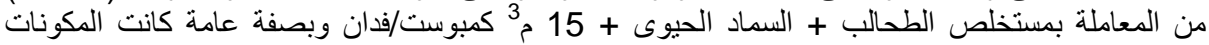
الكيميائية الرئيسية للزيت الطيار للأوريجانو هى الطى carvacrol, p-Cymene, ç-terpinene, a-thujene, a-myrcene, a-terpinene, ocymene, carvacrol methyl ether and caryophyllene. 